\title{
新学習指導要領における アクティブ・ラーニング
}

井田仁康

\section{アクティブ・ラーニングの捉え方}

小学校および中学校の次期学習指導要領が 2017 年 3 月に公示された。高等学校の次期学習 指導要領も2018年3月までには公示される。こ の学習指導要領（以後、新学習指導要領とする） の実施は、小学校で2020年、中学校2021年か ら完全実施、高等学校では 2022 年から学年進行 で実施されていくことになる。中央教育審議会 （2016）の答申によれば、新学習指導要領では、 資質・能力の育成が強調され、資質・能力は、 知識・技能、思考力・判断力・表現力等、学び に向かう力・人間性等といった、三つに整理さ れている。それら三つの資質・能力は、換言す れば「何ができるようになるか」であり、それ と「何を学ぶか」といった教科・科目等と、「ど
のように学ぶか」すなわちアクティブ・ラーニ ングとが関わり合い、社会に開かれた教育課程」 を実現させることが、新学習指導要領の特徵と なる（図1）。つまり、アクティブ・ラーニング は新学習指導要領において、教育方法に関する キーワードとなっているのである。

アクティブ・ラーニングは新しい概念ではな く、従来から用いられてきた。そのため、アク ティブ・ラーニングという用語には、様々なイ メージがある。藤井（2017）は、アクティブ・ ラーニングの導入として、「ペア学習」「グルー プ作業」「(ミニ) ディベート」「ジグソー法」な ど子どもたちが動く活動を形式的に取り入れた 授業がみられるが、それだけではアクティブ・ ラーニングではないと指摘する。つまり、（形式 的な)子どもの活動を取り入れれば、アクティブ. ラーニングと思っている教師 は少なくないということであ る。そこで、新学習指導要領 では、アクティブ・ラーニン グを後述する三つの学びと規 定し、アクティブ・ラーニン グという用語を用いずに、三 つの学びを「どのように学ぶ」 かを意味するものとして、ア クティブ・ラーニングという 用語と置き換えた。

図1 新学習指導要領の特徵 


\section{新学習指導要領での}

\section{アクティブ・ラーニング}

新学習指導要領でのアクティブ・ラーニング は、アクティブ・ラーニングという用語を用い てはいないが、「主体的な学び」「対話的な学び」 「深い学び」で表されている。「主体的な学び」 とは、子どもが主体的に学ぼうとする意欲であ り、自ら学習する計画、筋道を立てていくこと である。自らが学ぶべき課題を見出し、学習に 取り組むことが理想的ではあるが、学習内容が すでに決まっているので、学習の課題は教師な どによって提示されよう。その学習課題に対し て、どのように取り組んでいけばいいのか、筋 道を立てられ、その学びを振り返って改善して いく態度が主体的な学びといえるであろう。新 学習指導要領では、教師によるカリキュラム・ マネジメントが求められているが、児童・生徒 による学習マネジメントも求められているとい える。

「対話的な学び」とは、コミュニケーションに 基づく協働性を意味し、対話などを通して、協 働して得られる学びである。対話は、グループ

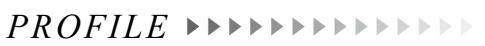

井田仁康 (いだ よしやす)

-筑波大学人間系教授

專門 地理教育 (社会科教育学)

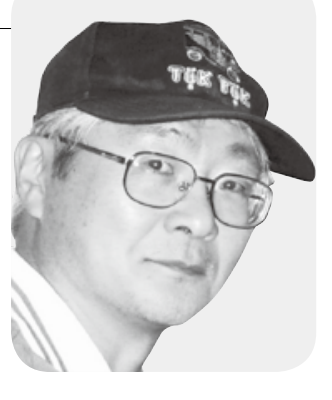

対話、地図を読み解くといった地図との対話な ども、対話的な学びとして位置づけることもで きよう。こうした対話は、今まで気付かなった ことや、新たな知見を得て、「深い学び」へと誘っ てくれよう。「深い学び」は、知識や技能を活用 して、思考力・判断力・表現力等を育成する学 びなのである。

こうした「主体的な学び」により学びの方向 性が決まり（つまり学びに向かおうとする力）、 「対話的な学習」で知識や技能が習得され、さら に習得された知識・技能が活用されて「対話的 な学び」が深まり、「深い学び」へとつながり、 知識や技能を活用して思考力、判断力、表現力 等が育成される。すなわち、井田（2016）が指 摘するように、アクティブ・ラーニングとされ る「主体的な学び」「対話的な学び」「深い学び」 はそれぞれに独立して捉えられるものではなく、 一連のプロセスとして捉える必要があろう。な お、こうした一連のプロセスとしてのアクティ ブ・ラーニングは、図2のように示される。 活動などでのクラスだけの対話 だけでなく、教師との対話や地 域に出て地域の人々との対話な どもふくまれよう。さらには、 自分自身との対話、景色を観察 することにより景色の意味を理 解する、すなわち景観としての 意味を見出す景色（景観）との

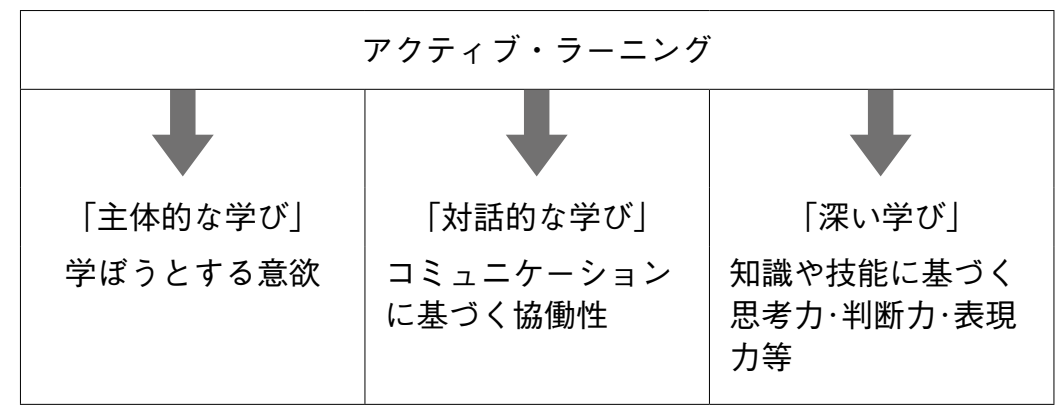

图2 アクティブ・ラーニングの概念 


\section{アクティブ・ラーニングへの 期待と課題}

新学習指導要領ではアクティブ・ラーニング、 換言すると「主体的な学び」「対話的な学び」「深 い学び」が教育方法として重視されている。こ の背景には、特に中学校・高等学校において、 教師から生徒への一方向的な教授だけで、生徒 が能動的に活動したり、思考したりする授業に なっていないという批判がある。小学校では、 子どもたちが自ら体験し、作業をする学習が多 いので、アクティブ・ラーニングが受け入れや すく、それに関する実践なども多く紹介されて いる。アクティブ・ラーニングの導入により、中・ 高等学校でも子どもたちが自ら考え、活動する 舞台が整えられ、より一層活気ある授業が展開 されることが期待できる。しかし一方で、対話 など活動させることが目的となり、知識・技能、 思考力などの深化がみられない、換言すれば「深 い学び」にいたらないという懸念もある。アク ティブ・ラーニングは、「主体的な学び」「対話 的な学び」「深い学び」の一連の学習プロセスで ある。学校現場で、アクティブ・ラーニングが 学習プロセスとして強く認識されないと、知識・ 技能の欠如、思考力の低下が指摘されるように なり、知識重視への教育へと転換していくこと になろう。

さらに、アクティブ・ラーニングを、あまり 硬直的、形式的に捉える必要はないと考える。 形式的に捉えることで、教師の独創性が活かせ なくなり、子どもたちも小学校から高等学校ま
で同じパターンで学習することで飽きがきて、 アクティブ・ラーニングでの授業を展開したと しても、授業の活性化が損なわれる可能性があ る。本稿では、「対話的な学び」については、グ ループ内でのクラスメートだけの討論、対話だ けでなく、自己との対話、学校外での地域の人々 との対話や景観や地図との対話など、対話を広 く捉えた。こうした対話を拡大して解釈するこ とにより、「主体的な学び」が促進され、「深い 学び」へとつなげやすくなる。こうした柔軟性 が教師には求められる。

アクティブ・ラーニングは教育方法であり、 これだけで教育が成立するわけではない。困 1 で示されるように、この教育方法が教科・科目 に応じた方法で効果的に活用され、子どもの資 質・能力を向上させていかなければならない。 アクティブ・ラーニングを意識するあまり方法 論だけに偏り、教育としての全体像を把握でき なければ、アクティブ・ラーニングを導入する 意義は極めてうすいといえる。

\section{文献}

井田仁康（2016）：アクティブ・ラーニングと統計地図. 統計, 67-12, pp. 33-38.

中央教育審議会 (2016)：「幼稚園、小学校、中学校、高等学 校及び特別支援学校の学習指導要領等の改善及び必要な 方策等について (答申)」

藤井千春（2017）: 資質・能力を育成するためのカリキュラム・ マネジメント.社会科NAVI, Vol.17, pp. 4-5. 